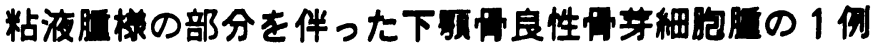

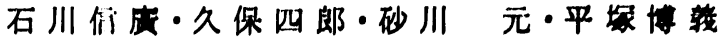

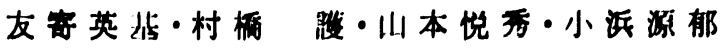 \\ 成松英明*
}

\section{Benign osteoblastoma of the mandible: Report of a case}

\author{
Nobuhiro Ishikawa - Shiro Kubo - Hajime Sunaxawa \\ Hiroyoshi Hiratsuka - Eiki Tomoyori - Mamoru MurahashI \\ Etsuhide Yamamoto • Gen-iku Конамa - Eimei Narimatru*
}

\begin{abstract}
The subject was an eighteen-year-old man with benign osteoblastoma of the mandible, and it was extremely rare tumor originating in the jaws. He had no painful swelling of the left side mandible.

Findings on physical examination limited to the mandible. Examination revealed that the lesion was a walnut size, firm rigid, and raised one. X-ray examination revelaod a radiolucent lesion with a radiopaque area of the anterior part, and the lesion extended from the second premolar to the second molar. Under general anesthesia, tumor extirpation was carried out. Histological features indicated a growth of woven and/or osteoid bone tissues, abundant osteoblasts with extensive myxoid degeneration, and histological diagnosis of benign osteoblastoma.

In this case, $\mathrm{X}$-ray and histological findings were atypical compared with previously reported cases because of presence of comprehensive myxoid degeneration.
\end{abstract}

Key words: Benign osteoblastoma, mandible, myxoid degeneration

緒

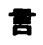

良性骨芽細胞庫 (benign osteoblastoma) は, 1956 年 K Jaffe, H.L.') および Lichtenstein, L.2) Kより同時に 命名されたるので，組織学的には，骨芽細胞の增殖が盛 んで，血管の豊富な間質をるった類骨や骨の形成を示す 良性の骨腫痬とされている，本腫理は比較的まれな疾患 で，その好発部位は四肢骨あるいは脊椎骨であり，額骨

札靦医科大学口腔外科学潇座

（主任：小浜源郁数授）

* 札晅医科大学附属病院梌査訩断部

（主任 : 黒川一郎数授）

Department of Oral Surgery, Sapporo Medical College (Chief: Prof. Gen-iku Kohama)

* Department of Laboratory Diagnosis, Sapporo Medical College Hospital (Chief: Prof. Ichiro Kurokawa)

受付日：昭和 60 年 3 月 22 日
領域に発生するるのは報告们が少なく，きわめてまれと

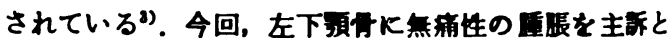

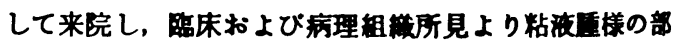
分を伴った良性骨芽細胸盾と診断された症们を保硢した ので，その㭢要を報告し，あわせて文献的考察を行った。

症 倮
息 者： 18藏 男性.
初昭和58年 8 月回.
主 诉: 左下碩部追脹.
家族厢：特記すべき本項なし。
既往歴：特記すぺき本項なし。

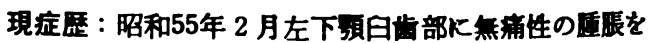

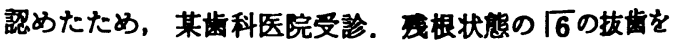
受けたか，同部の尰脹は消退しなかった。昭和56年 3 月 頃より畽脹は徐々に增大しまたた同部の圧庯が出現した ため，昭和58年 8 月某齿科医院を受診した。.X線諗査に より左下額骨に透過像を指摘され，精㚗のため当科を稆 


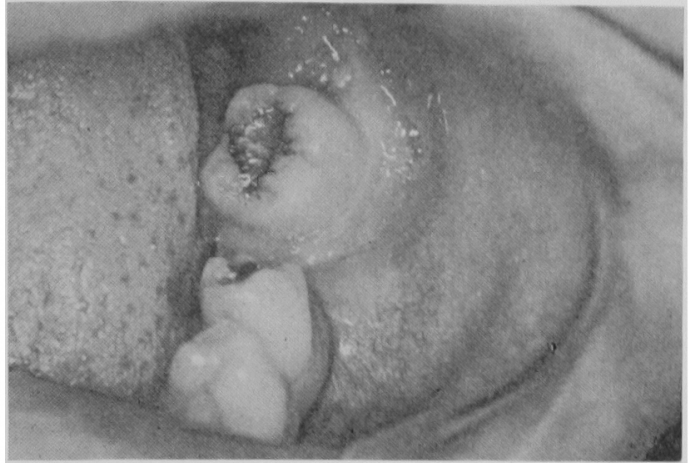

写真 1 初萻時口腔内所見

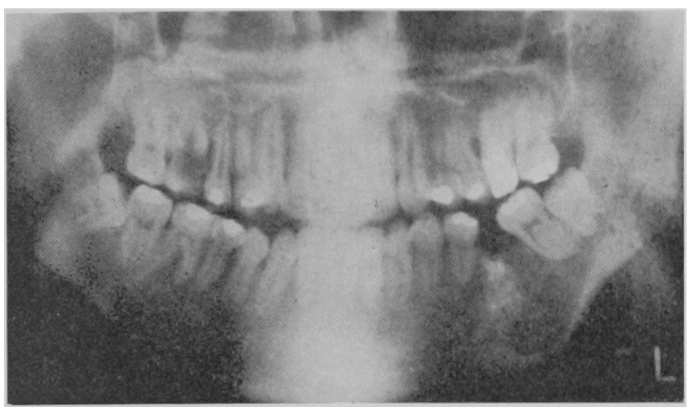

写真 2 初診時X線所見（パソトモ）

介され来院した。

現 症：栄盖状態良好, 体格中等度, 顔貌は中や左右 非対称で左下顠部に胡桃大，骨様硬，び漫性の腫脹を認 めるも, 自発痛, 王痛および同部の発赤は認められなか った。 た，開口障害，下口唇麻痺执よび顎下，臨下り ンパ節の尰脹る認められなかった。

口腔内所見： $\sqrt{5} よ り \sqrt{7}$ にわたる歯肉頓移行部に胡桃 大，骨样硬の膨隆を認め，同部函肉粘膜は軽度の発赤括

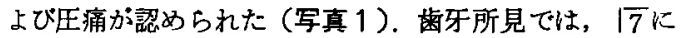
軽度の動摇が認められたが，電気歯䯣診断では $\mid$ 57 とも 生活反応を示し，打診痛は認められなかった。

X線所見：パントモグラフィーによるX線所見では， 病巣は $\mid \overline{5}$ の近心部から| 7 の遠心部にわたり, 胡桃大, 境界明瞕な畉円形の陰影を呈していた。その前方部は， 石灰化を思わせる小指頭大のX線不透過像がられ，後 方部では，䳝卵大，泡洙状の骨吸収像が認められた。同 病変周囲の骨硬化像は認められなかったが，骨皮質は軽

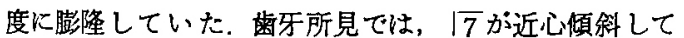
いたが, $\mid \overline{57}$ とも歯根の吸収は見られなかった(写真 2 ).

臨床検查所見：初診時アルカリフォスフォターゼ 189 単位と高値を示した以外は，とくに異常所見は認められ なかった。

臨床診断：左下顎骨良性腫湟.

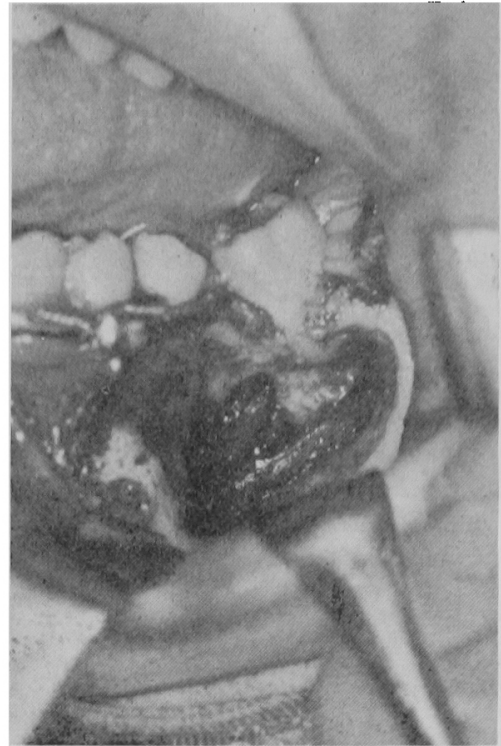

写真 3 術中所見（腫游摘出後）

処雷および経過：昭和58年 8 月—, 上記臨床診断の あとに試験切除を施行し，粘液腫様変性を伴う良性腫湯 性病変の診断を得たため，腫晹摘出を目的として9月 口入院した，手術に先立ち，摘出術施行後の下顎骨の安 静，補強の目的で，上下䫇崡牙を三内式線副子で固定し たのち，同年 9 月, GOF 全麻下に，口内法により

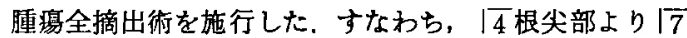
遠心部に扣よぶ頝側粘膜に孤状切開を加え，菌肉骨膜升 を剩雄翻転し，同尰瘍部を麗出させたところ，膨隆部の 骨は表面粗造であったが，尰瘍後上方部は一部に生検施 行時の骨皮質の除去による骨欠損があり，同部には赤褐

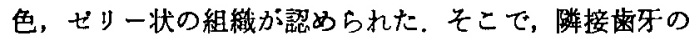
保存につとめ, 骨,ミにて腫瘍周囲より切除，摘出を行 ったところ，腫晹前方部は一塊として容易に摘出され， また後方部は，骨欠損部周囲の骨を除去したのちにぜ リー状の組織を鋭匙にて小塊に分けて摄爬し摘出した (写南 3).

なお，舌側扣よび下顎下縁の骨皮質はほほ健常であ り，また下雪慒血管神経束は尰瘦下方に王迫されて括 り，同部の損賃に留意しながら，骨整形を行ったのち， 摘出膑の骨面を倲結乾燥脳硬膜 (Lyodura作) にて被覆 し，アクロマイシン軟事がーゼを挿入，手術を終了した。 また，術後より1週間，下䫇骨の安静をはかるため左右 1本ずつェラスティック・ゴムにて開口制限を行った. 術後絓過は良好で，9月士退院した，その後，外来通 院にて経過観察を行ったところ，䳝卵大の摘出腔は，漸 次縮小し，術後 7 か月目には完全に消失し，良好な上皮 化が観察されたまた， 7 の動摇も改善され，類の変 


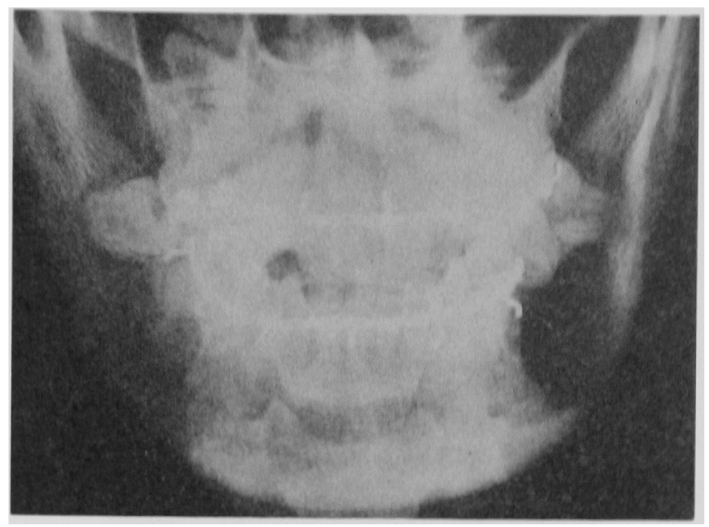

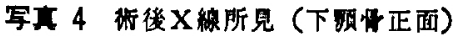

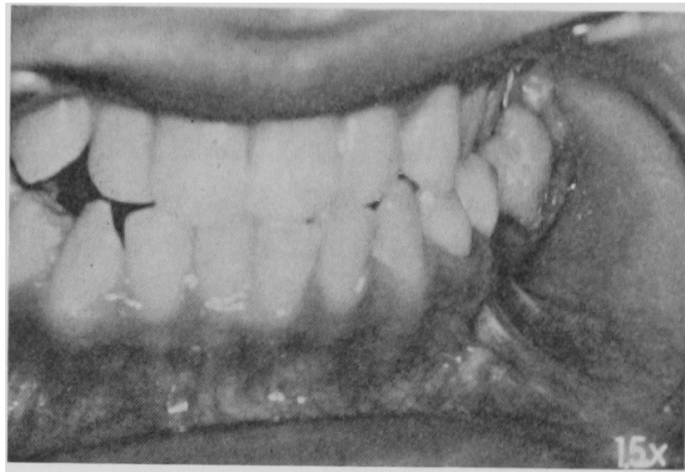

写索 5 摘出嵝 7 か月の口腔内所見

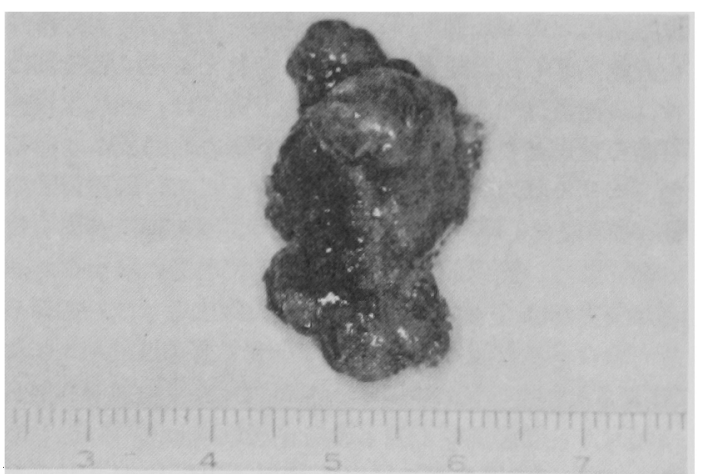

写高 6 摘出物所見（腫瘦前方部）

位，咀哷等の機能障害を残すことなく，臨床所見および レントゲン所見でも再発の徽候は認められない(写真 4, 5 ).

摘出物所見：一塊として摘出した前方部尰湯は，小指 頭大，赤褐色，弾性硬，表面相造であった，小塊に分け て摘出した後方部腫晹は, 赤褐色，柔軟なぜリ一状を星 しており，また，前方部摘出物の一部にも同様な組穖の

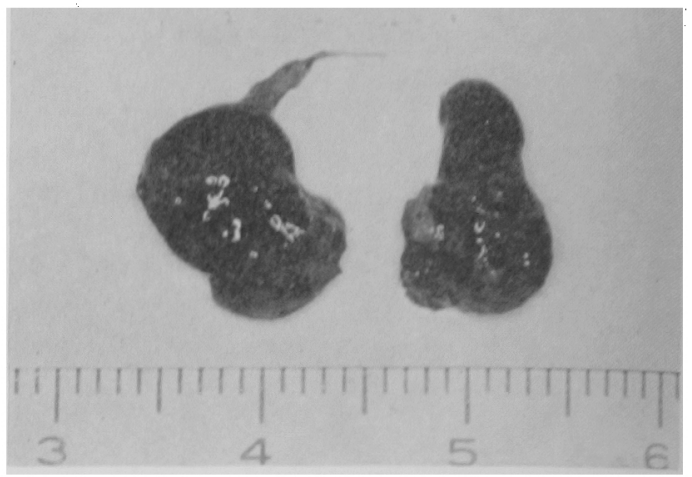

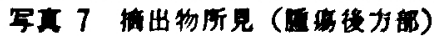

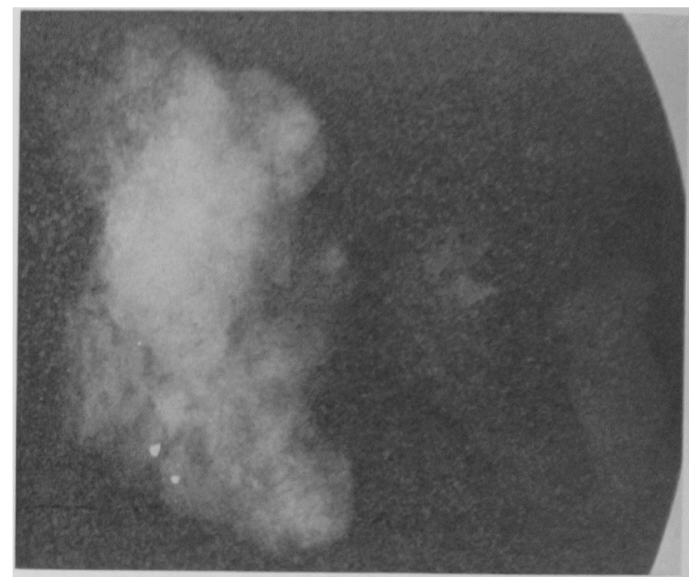

军真 8 掎出物X線所見

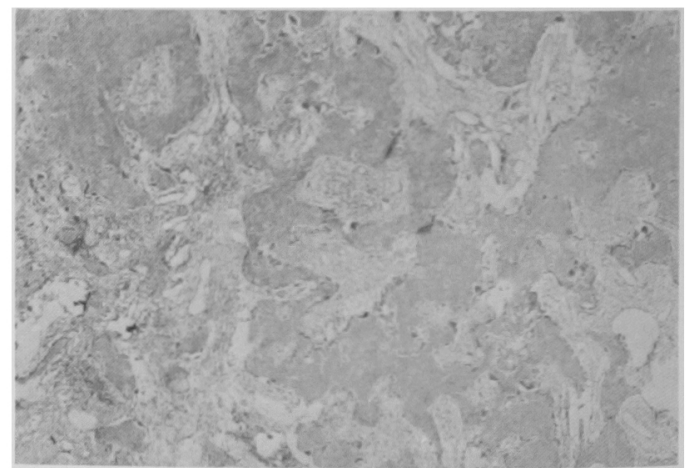

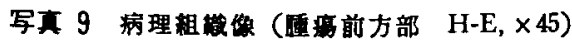

付着が珰められた（写真 $6 ， 7$ ）。

摘出物のX線所見では，X楾透過像とX線不透過像が 不規則に認められ，その中心部ではやや不透過性の強い 所見を呈していた．また後方部ゼリ一状の組織は，X線 透過性で，石灰化物を思わせる所見は楒められなかった (写真 8 ). 


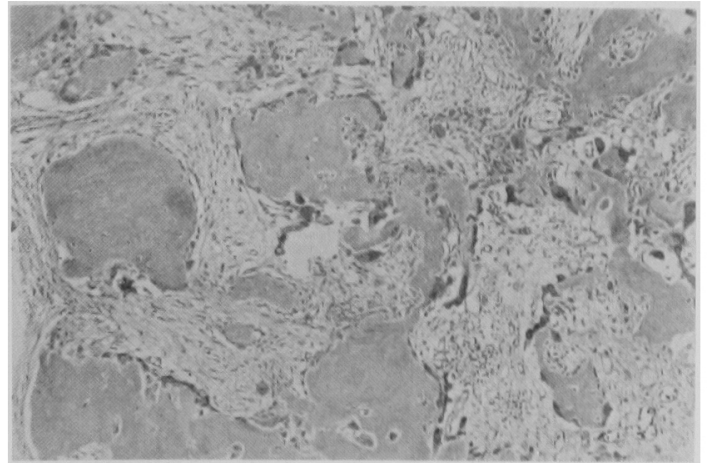

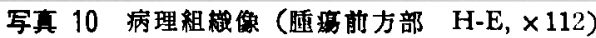

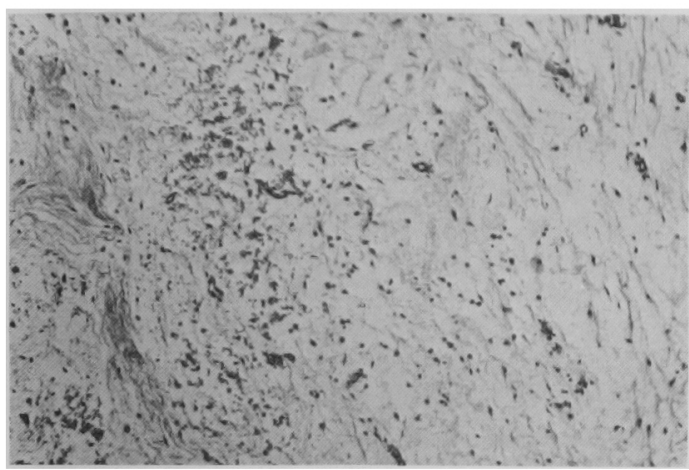

写真 11 病理組織像（畽瘍後方部 H-E, × 112）

病理組䋐学的所見：腫瘍前方部では，不規則な類骨様 組織や梁状骨の形成が多量に認められ，その周囲には， やや大型, 類円型の骨芽細胞の增殖が認められた。間質 は疎性結合組織より成り，血管が豊富で，骨に隣接して 破骨細胞も多数存在していた（写真 9，10）。

また，腫䄇後方部のゼリー状の組織は，紡錘型細胞上 り成る線維組織で占められ，分葉状に広がり，その分布 は韩で細胞の異型性は認められなかった（写真11）。

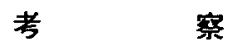

本尰瘍の全身に和ける発生頻度は，全骨腫瘍の $1 \%$ 以

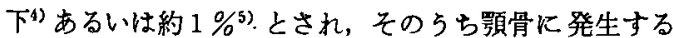
るのはきわめてまれで, 全骨芽細胞腫のうち約 $10 \%$ とさ れている. 本尰場の顎骨領域での発症例は，調査し得た 限りでは，われわれの症例を含めて，43例であった。 の5ち, 男女比は，男性28例 (65.1\%)，女性15例 (34.9 $\%$ と 1.9:1の割合で男性に多く発症し，平均発症年 路男性19歳，女性16歳，全体の平均は18.6歳で，10歳 代までに受診したものが69.7\% (30例)，30 歳以下では $86.0 \%$ (37例) であった. 全身に発生した本腫瘍の発症 年㱓扰よび性差に関して，Huvos の報告らによれば，

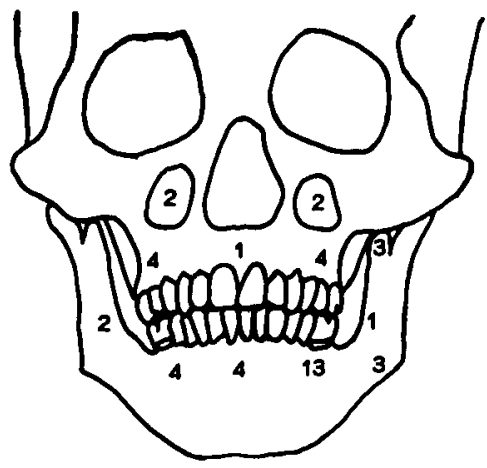

图 1 颚骨に発生した主性骨芽租胞腰 43例の発症部位別例数。

364 例中平均受診年路は 17歳，性別では 2：1 と男性に

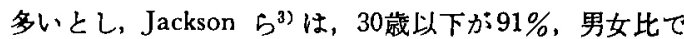
は1.91：1て男性に多くみられるとしており，䫑骨領域 の本尰場と比べると，後者では好発年龄はやや高く，性 別でははぼ同程度で男性に多く発現する傾向がみられ たまた影骨内の発症部位別頻度では，上額13例 (30.2

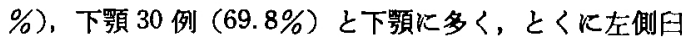
歯部では30例中13例（43.3\%）を占めていた（图1）。

本腫瘍の臨床的特致として，腫脹ならびに局所の疼痛 があげられる，疼痛の程度は，類骨々腫よりも㱍であ

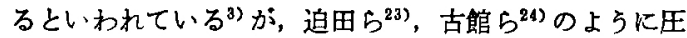

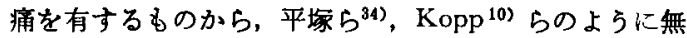
痛性のものなと，多様である，本症例では自発痛はない が，腫脹部煩側粘膜に軽度の圧痛を有する程度であっ た. 一般に本腫瘍の発育は, 骨内に発生し緩徐に増大し， 骨皮質を非薄化し，膨隆として認められるが，骨皮質を 浸潤，破壊して外部に增大寸ることは少ないとされてい る. 本症例では， れたが，術中所見では腫痬の発育による骨皮質の破境は 認められなかった。

本腫瘍のX線所見について，初期においては骨梁や類 骨組織が乏しいため，X線透過性の像を呈するが，畽湯 が成熟するに従って，類骨梁が增加し石灰化が進行する ため，不透過性になるか，あるいは透過像と不透過像が

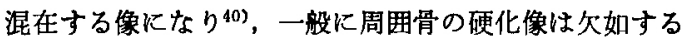
が，軽微であるとされている2，

また，本尰瘍の病理組織学的所見では，新しい病巣て は，骨芽細胞が豊富に増殖し，梁状に類骨組織が形成さ れ，骨梁に接して破骨巨細胞が認められる，また，閒質 は豊富な毛細血管に富も線維性組織よりなっている，古 い病然では，石灰化した骨質に富み，骨芽細胞は減少す る ${ }^{40)}$.つまり，尰瘍の新旧によりX線所見おょび病理組 織学的所見の様態も多様である。しかしながら，類骨や 


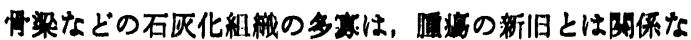

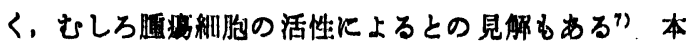

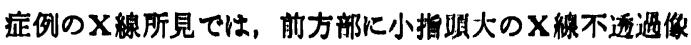

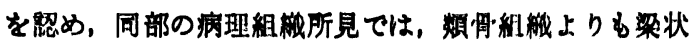
骨が多くみられ，具芽細胞の增殖もそれ程著明ではなか

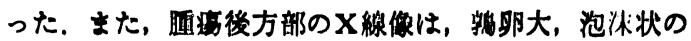
X線远過像を是しており，同部掉比物の病理組織所見で

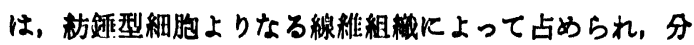

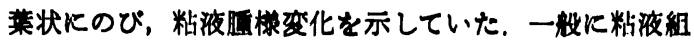
膱は，胎生児のはじめに间葉の大部分を占めているか，

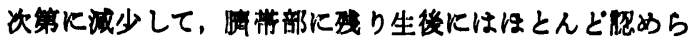

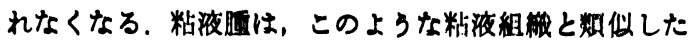

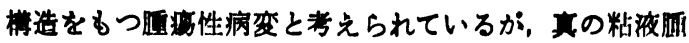
はまれなもので，多くは他の間葉性細胞起源の病变の装 性であるといわれている(2)．以上より，本症例の病想を 検討したところ，石灰化像が強いこと，組織学的に冎梁 が多くみられたことなどから，嗹瘍細胞の活性が就かっ たか，あるいは，與期間存在していた良性骨芽細胞腫 で，その一部が，何らかの影䇾を受け，粘液变性におち いったと推定された。本腫疸の報告例では本症例のよう な強い粘液変性を伴ったものはなく，非常に特異な病態 像を呈する良性骨芽細胞嗹の 1 例と思われた。

本尰晹と爁別を要する疾患として，良性セメント芽細 胞尰, 類骨々腫および骨肉腫などがあげられる，良性セ メント芽細胞腫は，齒根との瘾着があること，形成され

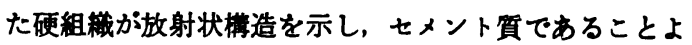
り鑑別され得る．額骨領域に発生する類骨々腫はきわめ て少ない(40)が, 病理組織像は本腫场之非常飞類似してお り，その鑑別は，X線所見において病策周囲に反応性骨 硬化像が認められ，また大きさが $1 \mathrm{~cm}$ 以下であるこ とから比較的容易とされている．本腫㻛と樶す鑑別を要 する疾患は，骨肉連である。骨肉腫は良性骨芽細胞腫と 比較して, 発育が急速であること, 組織学的に細胞の多 形性に富み，異型性が著しいことより容易に鑑別され 3.

本腫晹の治療方法としては，一般に提爬術および摘出 術か施行されている。しかしながら，その予後に関して は，提爬等の不適切な治療後に再発( ${ }^{6,13,18)}$ あるい:悪性 転化 ${ }^{43)}$ するといら報告もあり, 注意深い摘出術が推奖さ れている.

\section{結語}

18歳, 男性の左下䫏骨に生じた良性骨芽細胞腫の症例 を経釦したので報告し，あわせて文献的考察を行った。 本症例は, 臨床なよび組織学的所見で特異な病態像を呈 していたが，摘出術施行後 7 か月を経た現在再発の徵候 もなく経過良好である。
本淪文の蝶白は，第10回日本口此外科学会北日本地力 会に怙いて発费した。

\section{引用文 醋}

1) Jaffe, H.L.: Benign osteoblastoma. Bull Hosp Joint Dis 17: 141-151 1956.

2) Lichtenstein, L.: Benign osteoblastoma. A category of osteoid-and bone-forming tumons other than classical osteoma, which may be mistaken for giant-cell tumor or ostoogenic sarcoma. Cancer 9: 1044-1052 1956.

3) Jackson, R.P., Reckling, F.W., et al.: Ostooid osteoma and osteoblastoma, Similar histologic lesions with different natural histories. Clin Orthop 128: 303-313 1977.

4) Dahlin, D.C.: Bone tumons. General aspects and data on 6221 cases. 3 rd Ed, Chares C. Thomas publisher, Springfield, Illinois, 1978, p 86-98.

5) Huvos, A.G.: Bone tumors. Diagnosis, treatment, and prognosis. W.B. Saunders Co, Philadelphia, London, Toronto, 1976, p 33-46.

6) Borello, E.D., Sedano, H.O.: Giant osteoid osteoma of the maxilla. Report of a case. Oral Surg 23: 563-566 1967.

7) Krammer, H.S.: Benign ostcoblastoma of the mandible. Report of a case. Oral Surg 24: 842-851 1967.

8) Anand, S.V., Davey, W.W., et al.: Tumors of the jaw in west Africa. A review of 256 patients. Brit J Surg 54: 901-917 1967.

9) Byers, P.D.: Solitary benign osteoblastic lesions of bone. Osteoid osteoma and benign osteoblastoma. Cancer 22: 43-57 1948.

10) Kopp, W.K.: Benign steoblastoma of the coronoid process of the mandible; report of case. J Oral Surg 27: 653-655 1969.

11) Kent, J.N., Castro, H.F., et al.: Benign osteoblastoma of the maxilla. Case report and review of the literature. Oral Surg 27: 209-219 1969.

12）赤坂麻子，長山他：下预骨长発生した良

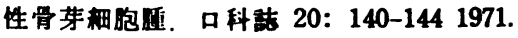

13）伊藤恽夫, 松消洋一, 他 : 玲しいBenign osteoblastoma の再発何人ついて。只科訰 20: 8478551971.

14) Brady, C.L., Browne, R.M.: Benign osteoblastoma of the mandible. Cancer 30: 329-333 1972.

15) Smith, N.H.H.: Benign osteoblastoma of the mandible; report of case. J Oral Surg 30: 288-292 1972.

16）伊藤輝夫, 兽我宏世, 他：下預筋突起発生し た benign osteoblastoma の一例. 日ロ外誌 19: 
183-185 1973.

17) Yip, W.K. and Lee, H.T.L.: Benign osteoblastoma of the maxilla. Oral Surg 38: 2592631974.

18) Remagen, W. and Prein, J.: Benign osteoblastoma. Oral Surg 39: 279-283 1975.

19) Hsu, S.M.: Osteoblastoma of mandible (report of case). J Formosan Med Assoc 74: 620-626 1975.

20) Farman, A.G., Nortj, C.J., et al.: Periosteal benign osteoblastoma of the mandible. Report of a case and review of the literature pertaining to benign osteoblastic neoplasms of the jaws. Brit J Oral Surg 14: 12-22 1976.

21) Labayle, J., Bacular, J., et al. : Benign osteoblastoma. A case situated in the maxilla. Ann Oto-Laryng (Paris) 93: 661-668 1976.

22) Brochériou, C., Raquat, J.P., et al.: Benign osteoblastoma of the mandible. Apropos of a case. Rev Stomatol Chir Maxillofac 77: 50531976.

23）迫田由起子：額骨の fibro-osseous lesion 第 1 編 単発性病変について，口病誌 44: 217-235 1977.

24）田中陽一, 下野正基, 他：下顎骨に発生した良 性骨芽稩胞腫の 1 例一光学影微鏡ならびに 電子顥错鏡的钼察。一日口外誌 25：406-413 1979.

25）入 久巳，犬山征夫：頭蓋骨，顔面骨における

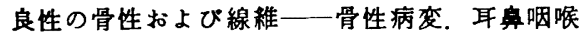
科誌 50: 179-185 1978 .

26) Chatterji, P., Purohit, G.N., et al.: Benign osteoblastoma of the maxilla (periosteal). J Laryngol Otol 92: 337-345 1978.

27) Greer, R.O. and Berman, O.N.: Osteoblastoma of the jaws; current concepts and differentiatl diagnosis. J Oral Surg 36: 3043071978.

28）奥山節子，鈴木鏵美，他：良性骨芽細胞腫の 1 例一一光影ならびに電影的榆討 (抄). 口科誌 27: 597-598 1978.

29) Nowsparast, B., Mesgarzadah, A., et al.:
Benign osteoblastoma. A clinico-pathologic review and report of a case. Int Oral Surg 8: 386-390 1979.

30) Miller, A.S., Rambo, H.M., et al.: Benign osteoblastoma of the jaws; report of three cases. J Oral Surg 38: 694-697 1980.

31) Schajowicz, F., Lemons, C.: Osteoid osteoma and osteoblastoma. Closely related entities of osteoblastic derivation. Acta Orthop Scandinav 41: 272-291 1970.

32）平榩博，山本悦委，他：下颚骨に発生した良 性骨芽稩胞僆の 1 例。日口外誌 28：225-230 1982.

33）南雷正男, 倉地洋一, 他 : 主性骨芽細胞随の 1 例. 日外誌 22: 681-685 1976.

34）小會墪，中村太保，他：䫓骨火於けるBenign osteoblastoma のX線学的㛟討. 拳故 22: 1-7 1982.

35）瀧川富雄，佐藤博，他：下矤に生した良性骨 芽耦胞腫と思われる 1 例。 日大歯学 53:6-13 1979.

36）古館 厚, 丸茂町子, 他：下顎骨良性骨芽細胞 腫の 1 例。口科誌 33: 140-149 1982.

37) Sidhu, S.S., Parkash, H., et al.: Benign osteoblastoma of the mandible. J Dentistry 8: 2542561980.

38) Danielidis, J., Triaridis, C., et al.: Mandibular ramus osteoblastoma. A case report. J max-fac Surg 8: 251-254 1980.

39) Van der Waal, I., Greebe, R.B., et al.: Benign osteoblastoma or osteoid osteoma of the maxilla. Report of a case. Int J Oral Surg 12: 355-358 1983.

40) 石川杬朗監修: 口空病理学 II. 永末書店, 京都, 1982，557-559頁.

41）小田島哲世, 篠崎文彦, 他 : 頡骨粘夜尰の 4 症 例。日口外誌 22: 551-556 1976 。

42) 武田勝男: 新病理学総椧。第10版, 南山堂, 東 京, 1971，351-356面.

43) Seki, T., Fukuda, H., et al.: Malignant transformation of benign osteoblastoma. J Bone Joint Surg 57: 424-426 1975. 